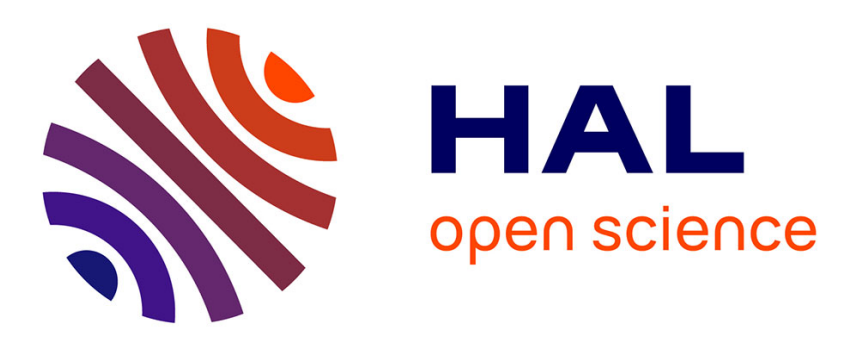

\title{
The Development and Current Features of the French Civil Service System
}

\author{
Philippe Bezes, Gilles Jeannot
}

\section{To cite this version:}

Philippe Bezes, Gilles Jeannot. The Development and Current Features of the French Civil Service System. Van der Meer Frits, Civil Service Systems in Western Europe, Cheltenham, Edward Elgar, p. 185-215, 2011. hal-01257027

\section{HAL Id: hal-01257027 \\ https://hal-enpc.archives-ouvertes.fr/hal-01257027}

Submitted on 15 Jan 2016

HAL is a multi-disciplinary open access archive for the deposit and dissemination of scientific research documents, whether they are published or not. The documents may come from teaching and research institutions in France or abroad, or from public or private research centers.
L'archive ouverte pluridisciplinaire HAL, est destinée au dépôt et à la diffusion de documents scientifiques de niveau recherche, publiés ou non, émanant des établissements d'enseignement et de recherche français ou étrangers, des laboratoires publics ou privés. 
Bezes Philippe, Jeannot Gilles, "The Development and Current Features of the French Civil Service System" in Van der Meer Frits (ed), Civil Service Systems in Western Europe, Cheltenham, Edward Elgar, 2011, p. 185-2015.

\section{The Development and Current Features of the French Civil Service System}

\section{Philippe Bezes and Gilles Jeannot}

\section{INTRODUCTION}

The French civil service is a complex institution to interpret as its historical development displays different ordering patterns with somehow contradictory orientations. The global image is well known: it is a unified merit and career based civil service system, traditionally associated with the idea of a strong state tradition (État is always capitalised) and the concept of service public encompassing an extensive number of public activities (from sovereign functions to industrial and commercial public services). Its legitimacy is rooted in the dominant values defining the "service of the state". They emphasize the idea of a disinterested civil servant serving the general interest and guarding the public good while also promoting the principles of impartiality, equality, adaptability and continuity. The robustness of the French civil service confronted to reforms has also been stressed.

More in-depth descriptions suggest a blurred picture mixing contradictory trends. The integrated statutory law, established in 1946 and regulating the rights and duties of all civil servants and the protection of citizen's rights towards public authorities, coexists with a highly fragmented structure corresponding to the large number of "corps" (about 1500 in 2000), the many groupings of public agents managed under similar conditions of recruitment, training, careers, promotions and pay. The various forms of self-management developed within the corps (exemplarily within the grands corps) contrasts with the idea of a legally unified civil service conforming to a uniform pattern throughout the country under the supervision of the Council of State (Conseil d'Etat), the highest administrative court. The typical career system has been distorted by the distinction between the rank (individually assigned to the civil servant according to its recruitment within a corps, grade) and the position (the role fulfilled, emploi) that introduces some flexibility and some elements of a job-based civil service: it allows promotion within the corps without job vacancy, transfer of job without loss of rank but also political appointments at senior positions and a privileged path to political career for higher civil servants who will occupy political positions without loosing their rank and belonging to the administration. In the same vein, the celebration of the general interest and the principle of neutrality is in sharp contrast to the high level of politicization for the top civil servants. At last, historical and current trends of development and transformations reflect more changes and low profile evolutions than usually recognized.

These distinct features of the French civil service can be partly explained by the successive regimes France has experienced (Monarchist, Bonapartist, republican, authoritarian and pro-German in occupied France for Vichy, parliamentary, semipresidential). The successive ruling elites were always suspicious of the inherited administration and the repeated attempts to consolidate the regimes led to complex dynamics of professionalization and reinforced autonomy (to rationalize administrative capacities to rule) together with politicization (to reward or to obtain loyalty, specifically at the top). After 
two centuries, the civil service did exist as an autonomous institution, differentiated around its specific administrative law but also highly fragmented through its division in corps and ministries. With the constitution of the Fifth Republic since 1958, the position and social prestige of senior civil servants became even stronger as a result of the success of the Gaullist political elites for whom top bureaucrats acted as a "relaying elite" (Quermonne 1982, p. 340346). They were strongly involved in developing new reforms and became closely identified with the new political elites who relied on them. Many senior officials then became committed to a regime that gave them new opportunities to enhance their careers. This structural arrangement giving strong power and high social prestige to top bureaucrats from the grands corps through discrete mechanisms of politicization was to be institutionalised in the following decades.

Although resilient in its inherited features, the French civil service has not remained unaffected by the neo-managerial trends and the changing political and economic context characterized by European pressures, trends towards decentralization, market-oriented policies, social transformations and new forms of political leadership. While the evolutions of the 1980s and 1990s appeared quite gradual and smooth, the new presidency of Nicolas Sarkozy has made public unusually sharp public critics against the French historical model. In his first major discourse on state reform on September $19^{\text {th }}, 2007$, President Sarkozy drew several systematic and radical trends for reform: the abolition of the corps system, the development of a job-based civil service, strong emphasis on mobility within the administrative system and between the three branches of the civil service (state, local authorities, hospitals), financial incentives to leave the civil service, possibility for the new recruit, but only for specific jobs in the French bureaucracy, to choose between acquiring the statute of 'civil agent' (with its pre-fixed rights, obligations and rewards) or preferring a private law contract he can negotiate by mutual agreement with possibly better wage conditions in exchange for the loss of a career-based appointment and a security of tenure. From October 2007 to March 2008, a major conference on the values, missions and occupations of the future French civil service took place. Bringing together experts, civil service trade unions, ministries and representatives of the Ministry for Budgeting, Public Accounts and the Civil Service, the conference produced a 'white paper' on the future of the French civil service (Silicani 2008) aimed at framing the possible reforms and at giving legitimacy to the new political goals. Although not systematically adopted yet but already implemented along several lines (mobility, intense movement of mergers of corps), this global program could significantly transform, if accomplished, the historical pattern of the French civil service.

In this chapter, four issues are examined. The first section is devoted to the historical development of the French civil service. The second section focuses on the various dimensions of the internal labour market while the third one addresses the issue of politicization. The fourth section analyses the recent transformations at stake and the way they potentially challenge the existing features of the French civil service system. The conclusion draws some perspectives of evolution due to these changes.

\section{The Development and Transformations of the French Civil Service System: Historical Trends}

\section{Origins: The Ancien Régime and the set-up of central administrative capacities ${ }^{1}$}

\footnotetext{
${ }^{1}$ Most of the text of this sub-part is taken up from the initial chapter on France by Marie-Christine Meininger (2001) in the book edited by A. J. G. M. Bekke and Frits van der Meer. We thank her for authorizing us to use her analysis of this first period.
} 
The development of the French civil service developed together with the emergence and growth of the modern state. During the Ancien Régime, the centralisation process steered by the monarchy led to the creation and reinforcement of administrative organizations in order to overcome rival powers (nobility, intermediate bodies, local powers, etc.). The power of the absolute monarch relied on the development of its administration (Legendre 1992 ; Boscher 1970; Mousnier 1974; for overview, Rouban 1988; Burdeau 1989; Thomas 1995; Dreyfus 2000). The establishment of a permanent professionalised army and the distinction between the King's property and public property were the first expressions of this evolution from a personalised to a statist rule. Several administrative positions and functions were gradually created, reflecting both the various attempts of the monarch to extend its steering capacities and the complexity of the Ancien Régime society as illustrated by the social status granted to the employees of these new administrative bodies and by their different forms of autonomy and dependence from the King. In the seventeenth and eighteenth centuries, the French civil service was far from being as homogeneous as the Prussian administration. Three groups can be distinguished:

- officers, having inherited their charge, responsible for justice and finances issues and, for a few of them, forming a first group of top civil servants from the nobility (the corps des maîtres des requêtes);

- public servants commissioned for a specific task (commissaires) who could be dismissed at the discretion of the monarch: in this group, we find state councillors and officials representing the king in the provinces (governors, intendants ${ }^{2}$ ) or abroad (ambassadors) ;

- a third category, called 'commis' or 'employés' (clerks), which prefigures the modern civil service as staffs of the emerging ministerial bureaux. Being appointed, they received a salary and some kind of allowance, and were able to enjoy a retirement pension. Nevertheless, their recruitment and career were subject to patronage and favouritism.

This diversity resulted in conflicts and divisions, especially between the nobility, holding their charges from inheritance, and those who represented the monarch as public agents (of common birth). The increase in the number of hereditary posts led to the reinforcement of patrimonial mechanisms over which the monarch exercised no control. However, the administration facilitated the reinforcement of the monarchy, enmeshing the activities of society within codes and rules and acting as a mediator between the monolithic activity of the monarch and a stratified and corporatist society.

During the eighteenth century, features of a professionalised bureaucracy emerged for two major reasons (Meininger 2001). The first was the development of technical functions such as public works and roads: the most striking example was the creation of a specific corps of civil engineers (1716) and of a dedicated school in 1747 (Ecole des Ponts et Chaussées), the first school of administration. It illustrates the emergence of a technical role for the state, which acts more frequently like an entrepreneur, creating the infrastructure for economic activities. The second reason was the growing importance of offices (bureaux) in preparing the decisions taken by the secretaries of state or the general controller of finance, especially at the

\footnotetext{
${ }^{2}$ During the Ancien Régime, collecting taxes was not a task of the monarch administration but was entrusted to the members of a corporation called Fermiers généraux.
} 
end of the Ancien Régime, as a consequence of ministerial instability and centralisation. However, despite some attempts to abolish the transmission of charges by inheritance or to reduce the role of private interests, this system was not significantly altered before the revolution.

\section{The emergence of professionalised rules: the revolution and the Napoleonic period}

The revolution first brought the abolition of privileges, amongst which the property of charges, and established new principles such as the principle of equal access to public offices and charges, without any other distinction than those resulting from talents (Declaration of Human Rights Art. 6). During the revolution, the composition of the civil service was altered. The nobles disappeared and representatives of the middle class entered the service. Another major consequence of the revolutionary period, following the reinforcement of the executive power, was the explosion of staffs in ministerial bureaux. The creation of new ministries (Justice, War, Foreign Affairs, Navy) and the war led to the appointment of many public employees whose number increased from 600 in 1789 to 7000 in 1799 (Church 1981) but one-third of recruited ministerial officials, at the end of the Directoire (1799), had previously served under the Ancien Régime, particularly in the financial administration (ibid.). However, this growth, in a revolutionary context where the legislative power and the general will were celebrated, led to a distrust towards the bureaucracy as a dangerous force, due to its potentially excessive autonomy and to its fiscal cost (Rosanvallon 1990, p. 49-74). According to Rosanvallon, this produced a "cultural" or a structurally engrained difficulty to address the complexity of the relationship between the government and the bureaucracy and to think the conditions and limits of its autonomy. The civil servant (fonctionnaire) was viewed as an agent of the executive government and mechanisms of politicization were then justified as techniques of control.

As argued by Tocqueville, the Napoleonic period largely built upon the foundations laid by the Ancien Régime and reinforced the centralized structures of the state. Bernard S. Silberman nicely summed up the issue to be solved: 'how to integrate the highly fractionated structure of local elites/notables into a community with national interests as well as local ones' (Silberman 1993, p. 104). The Napoleonic solution consisted in the creation of a rationalized administrative organisation (départements), of the prefects and sub-prefects (the central government's appointees and representatives on all matters) and of the mayors, initially appointed by central governments or prefects. This structure was the basis for developing mechanisms of central steering, resting on an (idealised) uniform and hierarchical administrative model, with the prefects as its cornerstone (Wright 1992 ; Hayward, Wright 2002). At this time, the civil service hardly began its professionalization, constrained by different contradictory dynamics. Several typical French features structuring the civil service originated in this context.

The first is the existence of an autonomous corpus of administrative law (Cassese 2000), distinct from the common law, that was to become the law of the executive power, the administration and the civil service, structuring its organization and its relationships to citizens. It was decided that ordinary courts were not in charge of administrative conflicts within administrations or with the citizens. Initially designed in 1799 to advise the government and to draft bills, the Conseil d'Etat served as a "disciplinary organ" 
for state public agents and as a Supreme administrative court to solve administrative conflicts between ministries or opposing the administration and the French citizens. Civil servants, distinct from clerks, were then protected from being prosecuted or sued for facts related to their public activities ('guarantee for civil servants"). The second Napoleonic contribution was the first steps towards an 'organizational oriented civil service' (Silberman 1993, p. 10) based on a mix of i) early commitment in a bureaucratic role and career during the educational process ; ii) organizational boundaries that structure early commitments (specific courses of university training such as law or 'public' sciences in order to become a public servant, specific schools designed to train top civil servants and/or forms of apprenticeship program before being appointed) and iii) strong career predictability through an integrated internal labour market channelled by departments or controlling bodies and reinforced by a system of ministerial corps. These elements were designed, although gradually implemented, during the Napoleonic period (Silberman 1993 p. 108-119). Admittedly, Napoleon did not create the French grandes écoles (Ecole des Ponts et Chaussées, 1747; Ecole des Mines, 1793; Ecole centrale des travaux publics which was to become the Ecole Polytechnique, 1794 ; Ecole normale supérieure, 1874-95). However, Napoleon re-established them as training schools for various bodies of civil servants (engineers, teachers, lawyers, and the like). For instance, Napoleon created the position of trainee (auditeur) in the Council of State in 1803 to assist the Councillors, and trained young people to occupy administrative (prefects) and diplomatic careers. Similarly, his policy from the lycée and the baccalauréat to universities and grandes écoles was aimed at giving the state the monopoly and control over education based on merit (knowledge acquisition). These institutions were created to channel the entry to the civil service and to provide individual professional training and skills as main criterion for holding higher administrative offices. Forms of job stability appeared in the civil service.

However, strong mechanisms of politicization were also set up or extended from the previous period. Apart from the general principle of specific rules of law for the administration and its civil servants, no specific rules for recruitment, career, rights and duties for civil servants were established during the Napoleonic period (Dreyfus 2000, p. 118-120). This contrasted with the strength of discretionary appointments for top positions and the growing importance of favouritism and patronage at lower levels for employees and, to a lesser extent, for middle rank civil servants. Personal choices of prefects by Napoleon, executive nominations in the 'grands corps' (Conseil d'Etat or the Cour des Comptes) and the extensive use of ministerial entourages were the complementary structures of the emergence of an organizational orientation. Two dimensions have then been initiated in the Napoleonic context which were to remain "typical" of the French configuration: a dynamics of bureaucratization based on training schools and emerging requirements to enter the civil service and a dynamics of politicization.

\section{Civil Service Reforms Under Pressures for Politicization (1815-1940)}

Put in a nutshell, the Nineteenth century and the first half of the twentieth century with its numerous successive political regimes (Restauration, revolutions of 1830 and 1848, July Monarchy, Second Empire, Third Republic) stood as a long period of reiterated games opposing defenders of bureaucratic autonomy and professionalism on the one hand, and, on the other, parliamentary and party political groups maintaining forms of patronage, favouritism and politicization. Forms of politicization achieved a high degree under the July 
Monarchy when membership in the Chamber of Deputies was combined with being a civil servant (députés-fonctionnaires): this phenomenon resulted from the strategy of the executive, appointing deputies in administrative positions as a reward and favouring the election of civil servants in Parliament as a way to control them. At the same time and although initially modest in staff numbers, political entourage or ministerial cabinets grew: especially under Napoleon III when members of the Conseil d'Etat (Council of State) held positions but also under the Third republic when the aim of converting public agents to the Republican ideology was crucial and when ministerial cabinets began to facilitate the departures of top bureaucrats (from technical corps or the Inspection des Finances) to private firms. Personal relations and social criteria continued to prevail in appointments, which remained at the discretion of the head of the state or of the ministers. Above all, under the Third Republic, there were Republican parliamentary politicians belonging to the middle-class bourgeoisie or the professions (Charle 1991, p. 256-261) who increased their use of the Chamber of Deputies to gain control over and to colonize specific ministries (Interior, Ponts et Chaussées, Education) with state field administration. At this time, politicians in Parliament considered themselves as opponents to the state and to the higher social classes who were identified to it and who managed to control the access to the top administrative positions (Shefter 1994, p. 57). Indeed, upper classes families controlled the access to the senior civil service and a certain income was necessary to apply for the grands corps (Charle 1991, p. 261-267). Members of the aristocracy were recruited in the prefectoral and diplomatic career while only engineering schools were initially open to members of the middle-classes with recruitment by competitive exams, early established for technical corps (Meininger 2001).

More generally, gradual moves towards bureaucratization and professionalization of the civil service repeatedly took place. Somehow paradoxically, the 'grands corps' (especially the Conseil d'Etat, the Inspection des Finances and the Cour des Comptes), with the most socially elitist recruitment, appeared to be the first administrative organizations to be professionalized and bureaucratized as Republic ministerial politicians found interest in having reliable, competent and autonomous overhead institutions at centre level (Dreyfus 2000, p. 175-178). Competitive exams were set up respectively in 1872, 1879 and 1886 for the three administrative 'grands corps'. Foreign, colonial and military administrations also benefited from more selective recruitment and legal protection through the creation of a statute (1834 for the corps of Foreign Affairs; 1834 for military officers as described by Saglio 2005). The distinction between rank and position, a specific French feature for the civil service, was adopted at this period. However, competitive exams and rationalised system of promotion were only slowly introduced for middle-rank bureaucrats, street-level public agents and specifically "clerks" for whom political allegiance remained crucial, even during the Third Republic. Several other efforts towards rationalization were gradually developed on different issues (Meininger 2001): the emergence of a hierarchical structure within ministries, the development of regulations on salaries and working hours, the organisation of careers and promotions (the career predictability being the motivation for entering the civil service), the set up of unified disciplinary rules for civil servants and the institutionalization of these elements as "rights" (to receive a salary, to be promoted, to get a pension when they retire). However, this dynamics of professionalization had to mesh with the many groups of civil servants who based their recruitment and careers on political allegiances. The creation of a national school of administration in 1848 was immediately abolished in 1849 and claims for having done with favouritism remained strong during the Third Republic. Silberman's 
argument is here convincing. In France, while mechanisms of career and autonomy were set up, post-revolutionary monarchs, emperors and republican governments were reluctant and unwilling to create a fully autonomous civil service because of the political instability. Thus, the political uncertainty due to the frequency of leaders' turnover and the instability of regimes led to the building of a twofold dynamics: accepting and developing early bureaucratic forms of recruitment through training schools, concours and career 'to produce a pool of eligibles who could meet the standard of expertise' (Silberman 1993, p. 137) and, at the same time, among these already selected elites, maintaining modes of political choices and loyalty. During the Third Republic, however, three factors prepared the foundation for the establishment of a professional civil service. First were the reactions against patronage and discretionary power by the growingly influential associations of civil servants (anticipated forms of trade unions) and asking for regulation of careers and disciplinary procedures. Second, the value of professional competence gained considerable credit in the 1920s and 1930s in accordance with the anti-parliamentarism that prevailed in the civil service and with the increasing influence of organizational doctrines for reforming the administration. Third, at the beginning of the twentieth century, the jurisprudence of the Council of State played an important role in establishing principles such as the civil servant's right to review his personal file in case of a disciplinary procedure, or rules regarding the regularity of promotions (Meininger 2001).

During the all period, however, the French civil service remained highly fragmented due to its segmentation in multiple corps - cross-ministerial groupings of officials with the same conditions of service and their own particular methods of internal management and promotion - and the strength of the growing ministerial specialization revealing a highly Balkanized administration.

\section{Decisive Moves Towards the Professionalization of the French Civil Service on an Integrated Basis (1940-1980s)}

The troubled period of the Vichy regime (1940-1944) blurred the dynamics of evolution. Dominantly characterized by reactionary decisions such as the abolition of civil service trade unions and by antisemitic, xenophobic and political purges within the civil service, the authoritarian regime also strengthened the idea of obedience to the state and even set up the first statute for civil servants as a strategic mean to obtain political loyalty (Baruch 1997, 2000).

The creation of the Fourth Republic gave a new and larger base of support for a professionalized and more autonomous bureaucracy. A statut général de la fonction publique ruling the bureaucratic roles and careers was established in 1946 granting recruitment by competitive exams, the freedom of opinion, the right to unionise, the right of trade unions to take part in career management and decisions regarding the organisation of services through joint consultative commissions (commissions paritaires). The civil service was then systematically divided into four groups (categories A, B, C, D) depending on the level of recruitment. Although the right to strike was not mentioned, it was derived from the 1946 constitution and was recognised by the Council of State in 1950 (Meininger 2001). As analysed by Martin Shefter (1994, p. 58), this professionalization resulted from an alliance with lower-level officials and trade unions (specifically the CGT) and was negotiated by a top Gaullist politician and former top bureaucrat, Michel Debré, and the leader of the French 
Communist party, Maurice Thorez then minister of the civil service (Siwek-Pouydesseau 1989 ; Chevallier 1996). The 'organizational' orientation of the French Civil Service was also institutionalised in 1945 with the creation of the Ecole nationale d'administration (ENA) as the centralised grande école for administrative state top bureaucrats (Kessler 1978). The ENA was aimed at socializing the members of different corps with the same ethos while also organizing, through the final ranking, their appointment to a specific corps and to a ministry, all functions largely persistent in the next decades (Eymeri 2001). Other training schools for civil servants (police, tax, justice, health) were created at the same period. In order to build a cohesive group of senior "interministerial" civil servants aimed at promoting cross-ministry links, another initiative created in 1945 a generic and interministerial grand corps of managers known as administrateurs civils supposedly acting as ministerial aides and occupying the top posts in the central administration of each ministry. These institutions finished to shape the French civil service, resulting in a hierarchical definition of office and career $^{3}$, a weak number of later entry in the higher civil service and a twofold organization articulating a general statute for all to several specific rules for the various segments (corps) of the civil service organisation.

From 1946 to the early 2000s, this framework underwent no major changes except at the constitutional level. The principles established in 1946 remained in force during the beginning of the Fifth Republic even though they had to be adapted to the 1958 constitution which provided for a (new) separation between matters ruled by formal legislation and matters ruled by governmental regulations (Art. 34 and Art. 37 of the constitution); consequently, a new statute had to be published by the ordinance of 1959. In 1983-4, another statute was passed which reaffirmed the 1946 principles and extended them to local and hospital civil servants. Apart from this unification of the main principles (within those principles, a special legislation rules each branch of the civil service, and significant differences remain regarding recruitment and careers in local government), the 1983 statute widens civil servants' rights (for example civil servants can obtain leave in order to attend trade union training) (Meininger 2001). The reform was launched by the socialist and communist government as both an ideological claim from the Communist minister of the civil service and as a strategic electoral issue in conjunction with the 1982 decentralization policy. Indeed, the communists obtained the rationalisation and extension of the statute as a counterpart in exchange for political support of decentralisation policy (Bezes 2009, p. 217225): moderate decentralisation personnel transfers were gained against extension and rationalisation of the statut.

\section{The internal labour market}

\section{The size, distribution and evolution of civil service}

Total employment in the French civil service amounted 5,2 million in $2006^{4}$. This included 2524440 for State civil service including teachers and military forces (fonction

\footnotetext{
${ }^{3}$ It is based on the notions of grade and corps, although the notion of 'emploi'/job exists in the French and the Spanish context, and opposed to the functional specialization based on the idea of job specification.

${ }^{4}$ Ministère du budget des comptes publics et de la fonction publique (2008), Rapport annuel sur l'état de la fonction publique. Faits et chiffres 2007-2008, Paris, La documentation française, 645 p. Without further references the data discussed here are drawn from this document and date of reference is 31 December 2006.
} 
publique d'Etat), 1662501 for local civil service (fonction publique territoriale) and 1014142 for public hospitals (fonction publique hospitalière). If the definition of civil service is relatively clear, the boundaries of public employment can be discussed. Civil service administration suggests the number of 6,033 million including public enterprises $(0,683)$, public organisations not included in civil service $(0,172)$ and private organisations mostly financed by public money like private schools under contract $(0,724)$. That is roughly one quarter of the total 25, 172 million employments in the country.

The French civil service has undergone two main changes during the recent years. First a dramatic shift in employment conditions in public enterprises. Post and telecommunications, formerly ministerial Departments are now more and more independent and, since 1990, new recruitments are made on a contract basis. If former civil servants have seen the advantages of their statute maintained, some of the employees of France telecom have been forced to join the State public administration. For electricity, even if the employees are not public servants, employment conditions have remained stable. This could change with the gradual opening of the market. Even if employment in public enterprises has not been reduced, private standards have become widespread.

Staff in civil service

\begin{tabular}{|l|l|l|l|l|l|l|}
\hline & $\begin{array}{l}\text { State civil } \\
\text { service }\end{array}$ & $\begin{array}{l}\text { Local civil } \\
\text { services }\end{array}$ & $\begin{array}{l}\text { Publics } \\
\text { hospitals }\end{array}$ & $\begin{array}{l}\text { Total Civil } \\
\text { service }\end{array}$ & $\begin{array}{l}\text { Total } \\
\text { employment } \\
\text { France }\end{array}$ & $\begin{array}{l}\text { Civil } \\
\text { service/ } \\
\text { Total } \\
\text { employment } \\
\%\end{array}$ \\
\hline 1986 & 2287458 & 1121383 & 756201 & & 4165042 & 19,4 \\
\hline 1996 & 2401791 & 1262361 & 825710 & & 4489862 & 20,1 \\
\hline 2006 & 2524440 & 1662501 & 953590 & & 5140531 & 20,5 \\
\hline
\end{tabular}

Rapport annuel sur l'état de la fonction publique 2007-2008 p. 272.

The second change has been the steady growth of local civil service (Fonction publique territoriale). Since 1986, total employment in local government increased of about $50 \%$ from 1, 12 million in 1986 to 1,66 million in 2006. This has been due to successive devolution policies starting from 1983 with staff transfer from the State to local administrations. It has also been the consequence of the creation of new public entities such as supra-communal bodies. Finally the change has come as a result of the growing legitimacy of local government.

A third change, repeatedly announced by politicians, i.e. the downsizing of state administration, did not happen yet. Even with successive staff transfers to autonomous public enterprises and to local government, the size of state civil service grew until 2002 and remains steady since. In 2006, a slight inflexion occurred linked to the decision to replace only one state administration retiree over two. However, this downsizing policy has not been able to compete with the growth of employment in local government. In the 2008 Budget, and after arbitration, the suppression of 22802 posts of state civil servants globally met the 'one in two' target except for the Education ${ }^{5}$, the Higher Education and the Justice Ministries which were able to plead special presidential priority. On the other hand, the Defence (- 6037), The Finances (-2380) or the Interior Ministries sustained the most considerable losses. About

\footnotetext{
${ }^{5}$ Around 13000 posts have been suppressed in the Education Ministry but this does not correspond to the objective of not replacing one retired civil servant in two.
} 
34000 suppressions have been announced for the Budget 2010 affecting the Education, the Defence and the Finances ministries.

The French Civil service is now divided into three categories according to level of recruitments level A (executives, teachers), B Middle level (graduates from secondary schools) and C lower levels (support administrative staff) ${ }^{6}$. The percentage of top level executives is higher in state administration $(23,3 \%)$ than in the private sector $(14 \%)$. In accordance with the new regulatory functions of the State, this share has increased. Teachers from elementary school to university are also members of category A. In the contrary, the lower levels have the largest share in local administration, which corresponds to the service functions of these organisations (refuse collection, maintenance staff for public space ...) as well as patronage.

\begin{tabular}{|l|l|l|l|l|l|l|}
\hline & A 1996 & A 2006 & B 1996 & B 2006 & $\begin{array}{l}\text { C } \\
1996\end{array}$ & $\begin{array}{l}\text { C } \\
2006\end{array}$ \\
\hline State civil service & 38,5 & 48,1 & 30,8 & 26,5 & 30,7 & 25,4 \\
\hline Civil , non teacher (state) & 19,4 & 23,3 & 24,1 & 34,7 & 56,5 & 42,0 \\
\hline Local civil service & 7,8 & 8,7 & 12,9 & 13,8 & 79,3 & 77,5 \\
\hline Public hospitals & 14,9 & 15,6 & 36,7 & 35,8 & 48,4 & 48,6 \\
\hline
\end{tabular}

Rapport annuel sur l'état de la fonction publique 2007-2008 p.51.

\section{Labour contracts}

The civil service is mainly made up of tenured civil servants. In the state administration, as illustrated in the historical part, they are member of "corps". Incumbents of these professional bodies are equal in terms of their rights and duties, their careers and job possibilities according to the provisions of special statutes that rule them. The initial recruitment of civil servants is carried out through competitive examinations based mainly on academic credentials and knowledge. They may then follow internal training. In a career system, individuals are recruited not only for a position or a job but for a career. During the career life-time, civil servants climb the grades of their corps. In many corps, this promotion has been based more on seniority than on merit, however there are some exceptions (Jeannot, 2005) In order to be promoted to another corps, a civil servant needs to pass an internal competitive exam. The large number of corps (up to 1500) used to be a traditional subject of irony. However the number has recently been dramatically reduced. By 2010 there will only remain 380 corps, and in fact $90 \%$ of civil servants belong to one of 140 corps.

Some employees of the public service are recruited under fixed-term contract: 296000 in state administration, 346000 in local government and 135000 in hospitals. The fixed term contracts respond to needs for specific competences or are used tools in the quest for flexibility. In some cases (such as subsidized employment) it must be considered as the implementation of a social policy. In the state administration it represents $11,7 \%$ of employment and $20,8 \%$ in local administration. A good part of the contractual staff is concentrated around a few functions: education assistants helping teachers in schools, researchers or neighbourhood wardens. In state administration the fixed-term contracts mainly concern entertainment officers whereas liaison officers in local government. A longitudinal approach (study of the carriers of individuals entering the civil service on a given year) of external mobility shows that beyond five years of employment, employees of state civil

\footnotetext{
${ }^{6}$ The category D was suppressed in 1990 and merged with the category C.
} 
services do not leave their jobs as some in fact have stable contracts and others secure their employment by passing internal exams in order to enter a corps. Thus, a threefold distinction should be made between unstable agents, working for less than five years, stable agents under contract and tenured civil servants. (Bessière and Pouget, 2007).

\section{Salary system}

Basic salary depends on membership in a corps. Each corps has a salary grid. The hierarchy between the salary grids correspond to the hierarchy of the function, and is roughly the same in different ministerial departments. A clerk (category C) will be positioned at the same level in all the Departments (a monthly salary between 1400 and 1750 euros), an inspector of taxes or a controller of public buildings (category B) earns a monthly salary between 1400 and 2000 euros; an engineer's or a teacher's (category A) monthly income goes up to 3500 euros and a top engineer, a university professor or a judge also earn more or less the same salary (up to 5000 euros). Equality and transparency are in theory the master words of this system but, in practice, inequality and non transparency are the rules, in particular through a specific bonus system specific to each ministerial Department.

Salary supplements are related to ministerial Departments and their amount differs from one Department to the other. Education is at the lowest level $(10 \%)$, technical ministers (transport, agriculture, ...) at a medium level $(60 \%)$ and Finance Department is at the top. The top level bonuses are quasi secret. The figures below, given by Department of civil service, intentionally merge together the bonus rates salaries of senior executives of the Department of finance and the other less favoured Departments. The real hierarchy is in fact different. A policeman earns as much as a teacher and a university professor makes much less than a judge or a top executive of the Finance Department.

Annual salary of state civil servants (net in euros) bonus related to brut salary (\%)

\begin{tabular}{|l|l|l|}
\hline & Net salary & Bonus percent \\
\hline Directorate managers & 82319 & 61 \\
\hline Judges & 57548 & 50 \\
\hline Engineers & 57604 & 60 \\
\hline Military officers & 42977 & 57 \\
\hline University professors & 49585 & 9 \\
\hline Secondary school teachers & 23977 & 8 \\
\hline Elementary school teachers & 21723 & 5 \\
\hline Technician & 25951 & 31 \\
\hline Clerks & 19469 & 23 \\
\hline workers & 16804 & 16 \\
\hline Policeman an Prison & 22887 & 40 \\
\hline Soldier & 17690 & 23 \\
\hline Total & 26641 & 22 \\
\hline
\end{tabular}

Rapport annuel sur l'état de la fonction publique 2007-2008 p.528 
Salary patterns in the whole differ between the public and private sectors. On the one hand, there is less pay diversity in the public sector. On the other hand, wages in the lower positions are higher in the public sector than in the private while lower in the higher positions. Lucifora and Meurs (2006) have observed that male executives in the public sector (non teachers) earn $4 \%$ less that their counterparts in the private sector while it is $2 \%$ less for public female executives compared to private female executives. This difference is higher in Italy but does not exist in Great Britain.

\section{Real mobility}

Tenured civil servants, especially in State administration do not tend to leave to the private sector. However internal mobility is much higher inside the public service than it is in the private sector. We can distinguish geographic mobility (change of city and region), organisational mobility (lateral moves between organisations, changing ministerial Departments for example), and socio-professional mobility.

Geographic mobility is stronger than in private sector. In 2006, 3,7 \% of civil servants had changed place against $2,7 \%$ in the private sector. This has been mostly young civil servants (especially teachers) who, for example, are forced to accept a first job in the suburbs around Paris and who try to return in their region and managers who work from one region to another in order to progress in their career.

Nonetheless the road to organisational mobility is full of obstacles, especially that of mobility between Departments. If the personal management for a member of a specific corps is under the jurisdiction of a given Ministerial Department, then applying for a job in another specific Department implies complex procedures. Beyond these bureaucratic difficulties, there are also economic and social difficulties to overcome. Incumbent of the most favoured Departments are not willing to leave their place for newcomers from "poorer" ministerial Departments, and, more generally, will not offer the better promotions or positions to outsiders.

As for socio professional mobility, a longitudinal approach (Bessière, Pouget, 2007) revealed that one out of two state civil servants who entered in the category B in 1983 was hired as a member of the category A ten years later. These promotions have been made possible through traditional internal exams (30\% of recruitments in corps), structural reform (the elementary school teachers have progressively been recognised as category $\mathrm{A}$ ), and use of external exams. This very strong mobility is due to two phenomena. On the one hand the growing need for higher qualifications due to new regulatory functions in the State. On the other hand, recruitment of overqualified civil servants, due to a high level of unemployment in the country. The civil servants who had originally accepted a job inferior to their academic level, took advantage of the new pattern of competencies to accelerate their carriers.

\section{Diversity}

Representative bureaucracy has only recently become a subject of debate in France. Three themes are presently under discussion: gender, class and ethnicity.

There are more women in the civil service than in the private sector: $60,8 \%$ of staff for state and local government against $44,5 \%$ in the private. For executives, one among two is a 
woman in the public sector against one among three in the private sector ${ }^{7}$. Even in traditionally "male" professions (army, police, prison, technicians, etc.) the presence of women is growing. The bureaucratic and egalitarian system of corps offers good protection for women and the pay gap between the sexes is lower in the public than in the private sectors.

However, there is no symmetry in public management between women and men in terms of opportunity and power. Women remain underrepresented in higher management. The share of women in different setting could be different. A good indicator of real opportunity is the comparison between the ratio women/men in a higher position and the ratio women/men in the population who has access to this specific position (often the member of a specific corps). If the ratio equals 1 , we could consider that opportunities are equal. In fact this ratio never equals 1 . In 2006 the ratio was 0,52 for directors of central administration, 0,34 for prefects (préfets) and 0,45 for medium level management positions.

Civil service also offers good opportunities to people from the lower-income classes. $38,4 \%$ of the children from blue-collar families who have entered civil service have become member of cadre or intermediary professions. The figure is only $25,5 \%$ for those who opted for the private sector (Audier 2000). This could be linked to a diploma effect. With the equivalent degree, public servants have more modest origins in the public than in private sectors.

Ethnicity remains a delicate subject in France. There are no ethnic statistics and one must use indirect question such as place of birth of parents to be able to examine the question. Even so, these data show at least a certain difficulty for the children of immigrants from the 1960s to enter public administration. The unemployment rate of individuals with two parents born abroad is twice as big as that of people with parents born in France. The children of immigrants represent $1 \%$ of staff in the private sector and $0,6 \%$ in the public sector. The gap remains even after cross-control with diploma, age or father's profession (Pouget, 2005).

\section{Labour relations}

The civil service has a number of peculiarities regarding labour relations. These are essentially related to the weight and role of the state in French society. As the country's main employer, it adopts appropriate management rules and techniques in terms of recruitment, wages, training, promotion and career advancement. This feature also relates to its role as a public authority, mediator and defender of the general interest. Civil servants, at the service of the state, embody it as much as they represent it. They consequently become the vehicle of its prerogatives and hence an employee, unlike others, to whom a 'special legal system, departing from the usual rules of labour legislation and determining a particular set of rights and obligations' applies. As a direct consequence of the significance of this status, the rules governing labour relations in the civil service are highly formalised, in the form of codified laws and regulations.

The rate of trade union membership in the public sector is 20 percent compared to 10 percent in the private sector (Siwek-Pouydesseau 2001). This rate is not spread evenly, with 80 per cent in the police, 30 per cent in education, 25 per cent in finances and infrastructure and 15 per cent in the hospital sector. Levels of conflict in the public sector are equally high, although available figures lack precision (Denis 2003). Mouriaux (2000, p. 160) has traced

\footnotetext{
${ }^{7}$ Source : enquête emploi en continu, INSEE.
} 
this asymmetry between the public and private sectors back to 1986 when mobilisation started to weaken steadily in the private sector and simultaneously to increase in the public sector. Rouban (2004a) pinpoints the rise of conflict in the civil service to the autumn 1995 strike with an explosion of lost individual working days (3 760 000) in the public sector. Although this moment was quite specific, 683,584 individual working days were still lost in 1998, 751,868 in $1999,1,650,338$ in 2000 and 1,115,331 in 2001. These conflicts, the result of a steep deterioration of the organisational climate in state services, are seen as being less and less generalised or imputable to a united trade union front. With more and more segmentation, it has been increasingly local and/or category-specific- a sign of the dislocation of work collectives.

Labour relations are both well developed, due to the strong presence of trade unions and institutions representing employees, and limited, due the absence of collective bargaining in the sense of a process leading to a convention or agreement (Saglio 2003). In fact the arrangements mentioned above are simply consultative. Yet absence of collective bargaining does not imply absence of negotiation in the sense of dialogue. Since the 1920s, union representatives have regularly been received by successive governments and, since the 1980s, negotiation has spread to new fields. These include revision of the civil service scales with the Durafour protocol in 1990, on-going education in 1989, 1992 and 1996 and the gradual reduction of temporary employment in 1996 and 2000 (Rehfeldt and Vincent 2002). More precisely, it indicates that civil servants are bound to the state by a particular relationship of a regulatory rather than a contractual or conventional nature. This means that the institutions representing civil servants are simply consultative bodies and that agreements signed by the partners have a moral and political value, without being legally binding.

In this context, 'renovation' of negotiations appeared necessary in view of their 'low efficiency' (Fournier 2002). Hence the white paper on labour negotiations in the civil service proposed two agendas. The first suggested change is devolution of collective bargaining. The official objective here is to link the locus of negotiation more closely to those of decisionmaking. The second proposed change is the 'renewal' of labour negotiations that first and foremost involves the re-establishment of bodies representing employees. Renewing it means allowing actors other than officially recognised unions to participate.

Bercy agreements of finance Department (November 2008) pave the way to the reform. Trade unions are recognised along their weight in professional elections. Agreement could only be recognised if signed by trade unions representing a majority of staff.

\section{Politicization}

As suggested in the historical part of this chapter, mechanisms of politicization have been set up and developed in the French context from the early Nineteenth century under the Napoleonic period. However, for the vast majority of state civil servants then recruited through competitive exams and schools and promoted through rationalized mechanisms after 1945, politicization at all levels via political control of appointments and careers gradually disappeared. Forms of politicization have persisted and have even been continuously and growingly used as structuring means for steering, producing loyalty and controlling administration in two domains: at higher level for top bureaucrats within the state through ministerial cabinets and discretionary appointments (political loyalty is there in balance with expertise and competences) and, at various levels, for the territorial civil service where the 
system of recruitment and career is slightly different from the state civil service and where politicization has remained more structuring.

The first main layer of this "politicization" process at the top can be found in recruitment to ministerial cabinets. From 1958 and 1962, the strengthening of the executive the offices of both President of the Republic and Prime Minister - allowed the increasing use and institutionalization of these mechanisms that came to reflect both support for and loyalty to a minister as well as policy expertise (for an overview on the all period, Bezes and Le Lidec 2007). General data on ministerial cabinets shows a significant and ongoing increase in the total number of cabinet positions in ministries from less than 300 people in the early sixties, about 500 in the 1980s reaching an approximate 700 in the 2000s. In 2001, within the second Jospin government including 34 ministerial and state secretaries portfolios, the number significantly rose to 584 then to 685 under the third Raffarin government (39 portfolios) in 2004 and to 664 people under the Villepin government in 2006 (for these figures, see Duport et al., 2007). In November 2008, members of ministerial cabinets reached an official total of 619 people under the Fillon Governement (Projet de Loi de Finances 2009, 37 portfolios) to whom 45 members of the Presidential cabinet should be added.

Top civil servants from the ENA have been massively employed in these politicized structured for several reasons. Ministerial cabinets are extremely powerful centres of decisions where public policies are shaped in interaction with central administrations - thus providing attractive positions to senior civil servants ready to serve the government of the day or experts in a specific sector. Serving in ministerial cabinets has also been a reliable path for career advancement as a means of reaching leading positions in central administrations or of obtaining public and private jobs as rewards - specifically for members of less prestigious 'grands corps' such as administrateurs civils - would not obtain so quickly through usual career paths.

However, a significant decline in the number of members of the three administrative grands corps (Inspection des Finances, Cour des Comptes, Conseil d'Etat) in ministerial cabinets has been observed from around 34 per cent between 1958 and 1972 to 16,6 per cent between 1984 and 1996 (Rouban 2004b), even reaching 10\% in a recent survey covering five cabinets (Prime minister, Budget, Interior, Justice and Labour) in four moments (1990, 1996, 1999, 2003) (Duport and al. 2007). On one hand, this has to be referred to the rising staffs and to the emergence of new functions in cabinets related to the still-growing professionalization of politics: specific political, opinion-polls and communication advisers have increased significantly since the nineties (Sawicki and Mathiot 1999) but also to the appearance of new staff in cabinets who are not civil servants any more but "either professionals or political party and association activists" supporting the government's action and called "political advisers" (Rouban 2007, 2009). On the other hand, top civil servants in cabinets from to the three administrative grands corps still monopolize the leading positions such as cabinet directors or co-directors. A significant change has also been identified by Luc Rouban (2007, p. 491-493), observing that 'ministerial cabinet membership is likely to become a true professional occupation' as some top civil servants have been spending quite a long period of their whole public career in the 1990s and 2000s being members of different ministerial cabinets (although in governments sharing the same political orientations) at different periods as competent issue experts.

A second crucial dimension of the French dynamics of politicization has been the full use of discretionary powers to appoint the top management positions in central administrations (about 185 directors) and even more political nominations (125 prefects, 158 ambassadors) for which recruitment belongs to the President and the government, specifically negotiated with the Prime Minister during the power-sharing periods (Schrameck 2001). The 
rate of turnover for the heads of ministerial divisions after a new election has significantly increased since the sixties (14\%). Rouban reported that 33 division heads (out of 170) were replaced during the first year of the Jospin government in 1997/1998 while 47 were dismissed during the first year of the Raffarin government in 2002/2003 (Rouban 2007, p. 488-489). Under the Sarkozy Presidency and the Fillon Government, media have highlighted a new acceleration of the rate of the turnover but recent data are scarce. Three observations can be made on the recent period. First, the turnover of prefects, traditionally higher than other public positions, seems to have even significantly increased. The president of the Association of the prefectoral corps, prefect of the Ile-de-France, mentions in October 2009 that $90 \%$ of the 125 regional and départemental prefects in territorial positions have been moved between 2007 and 2009. In 2007, with the presidential election of Nicolas Sarkozy, a significant move to tighten intra- and interministerial control have been made by redrawing boundaries between ministries, significantly reducing the number of full ministers and, most of all, drastically merging directorates in central administrations but also regional and departemental state units within ministries. The explicit aim was to generate cutbacks but also to strengthen the integration and coherence of public policy and to increase administrative responsiveness via a new hierarchy (for the full argument, see Bezes and Le Lidec, 2010). This dynamics follows a first move, initiated in 2004 with the creation of General Secretariats in all ministries, directly responsible to the Minister, with management authority over all departments and responsible for modernization and reorganization. This reshaped organization is likely to reinforce politicization as the reduction in the number of central and regional administrative directorates actually creates "super senior civil servants" with strategic and political orientations who enjoy more direct and loyal relationships, not only with their own minister, but also with the Head of State to whom they report (Bezes and Le Lidec, 2010).

Another robust mechanism of politicization in the French context has been the limited but growing number of senior officials following political careers and seeking for electoral office. Twelve prime ministers out of eighteen were members of grands $\operatorname{corps}^{8}$ while fourteen came from the civil service. Only two out of twelve right-wing Prime ministers (Barre and Raffarin) were not members of higher civil service. Since the early 1990s, the number of ENA graduates being ministers declined as only 24 per cent of ministers under Balladur in 1993 and Juppé in 1995/1996 were énarques (Kesler 1997) but key ministers -- Foreign Affairs, Defence, Economy and Finances -- were often énarques (Chevallier 1997). In the recent Fillon government, this number has drastically dropped: out of 15 ministers in June 2007, only one is a top civil servant and énarque. Out of 15 state secretaries (secrétaires d'Etat), two came from the ENA and one from the school of Polytechnique and the corps of civil engineers. However, the most recent trajectory for civil servants seeking political careers appear to move to elective office via parliament or, even more now, local governments. As an example, in 2003, out of the twenty-two presidents of French metropolitan régions, nine were top civil servants out of which four were members of grands corps.

At last, the local civil service (gathering 1748378 agents in 2007) has been historically built on rather distinct tracks, offering a mix between selective exams and high level of politicization for top management positions (Roubieu 1994) and for street-level agents and clerks for whom forms of patronage have been observed (Biland 2008). Politicization of senior management positions (a bit more than 3000 positions) in Regional and Départemental Councils and in big cities (more than 80000 inhabitants) has been fully institutionalised and functions as a spoil system with various forms of political loyalty and

\footnotetext{
${ }^{8}$ Four from the Conseil d'Etat (Debré, Pompidou, Fabius, Balladur), one from the Cour des Comptes (Chirac), four from Inspection des Finances (Couve de Murville, Chaban-Delmas, Rocard and Juppé) and three were diplomats (Messmer, Jospin, de Villepin).
} 
systematic replacements when local executives change after elections (Perrin, 2007). This movement has been even intensified at lower top management levels in the 2000s including now assistant general directors of administrative services in local authorities (ibid.).

There is no surprise that these various mechanisms of politicization result in increasing forms of "strategic politicization" (Rouban 2004c) or "functionally politicized" involvements among top civil servants (Eymeri 2003 ; Bezes and Le Lidec 2007, pp. 133-139; Rouban 2009) characterised by strategic overview of a specific policy, stronger commitments to the objectives, political choices and results of this policy and personal loyalty to the minister in charge. Of course, this political commitment should be understood carefully as top civil servants have always claimed, from the early Fifth Republic to the recent period, to hold technical and professional competences and to form a new 'modernizing' administrative elite (Dulong 1997; Gaiti 1998). However, recent scholars analysing the roles played by top bureaucrats suggest that the form of their involvements have evolved from "conviction and neutral expertise" to $\mathrm{i} /$ stronger influence in the design of goals and strategic instruments in policies (for neo-liberal economic policy, Cameron 1995 ; for health policies, see Geniyes, Smyrl 2008 ; for state reforms, Bezes 2007, 2009) and to ii/ higher political responsiveness to the political minister they serve in cabinet or in senior management positions in central administrations. It is, for instance, highly significant that, under the new Sarkozy presidency, several prefects, members of the most reactive grands corps to political inputs, have been appointed in the presidential entourage or in strategic positions in ministries (Bezes, Le Lidec, 2010).

\section{Recent Trends in Civil Service Reforms (1980s-2009...)}

Like in other European countries, several policies of administrative reforms were launched in the eighties and nineties in France (Bezes 2009). Although the reforms did not dominantly targeted the civil service per se, they started operating smooth departures from the historical institutional arrangements. Three distinct dynamics can be identified. The first one, continuously implemented by the Budget Division in the eighties and nineties, relied on cutback management policies on civil servants' wages and staff through depoliticized and low-profile techniques : they limited civil servants' wage growth and their purchasing power without public claims (Bezes 2007). The second dynamics, dominantly defended by left-wing governments from 1984 to 1991, developed a 'modernization' narrative of administrative reform proposing a 'public service oriented' programme emphasizing greater users' concerns, policy evaluation, experimentations of managerial tools (quality circles, managerial contracts) but also efforts towards better human resources management, vocational training and social dialogue with civil service trade unions. This narrative did not contain any bashing of bureaucrats neither challenged their legal protection. The 'Public Service Renewal' programme, launched in 1989 by the Prime minister Michel Rocard, nicely illustrated the trade-off between the gradual introduction of managerial instruments and the participation of public agents to administrative reforms. The third dynamics took place in the 1990s. Defended by right wing governments, the narrative offered a 'state reform' programme with strong New Public Management orientations and systematic announcements of the need to reshape the French administrative system in all its components (Bezes 2001). Dominant ideas in major public reports or in the Prime minister's plan (Juppé circular of the 26 July 1995) contained a comprehensive planning of administrative reorganizations through various measures: separation of steering functions from operational ones, restructuring of central administrations, devolution to state field units and their reorganisation under the prefect's leadership, clarification of competences between state and local authorities. Last but not least, 
reform plans also emphasized the systematic use of managerial techniques, an important reform of the budgetary procedure and some proposals for reforming the French civil service: the reduction of the number of corps, a more flexible pay or a reform of senior executives' career. Major ministerial players (the Civil Service Ministry, the Finance Ministry's Budget Department, the Interior Ministry) simultaneously invested time and resources in pursuing some of these distinct measures but with rival interests and conceptions. From this, resulted significant moves towards more drastic evolutions of the state territorial organization, the budgeting process or human resources management but these ideas were to be developed and adopted more drastically after 2000 (Bezes, 2007).

Indeed, by the early 2000s, several structuring features of the French civil service became more systematically object of critics and of reform proposals in a new context. The global issue became more acute in 2000 when the General Planning Commission made public the forecast that $45 \%$ of state public agents would be retired by 2012 . Reducing the numbers of civil servants to this extent required the setting up of a genuine human resource policy, which had proved difficult to implement in the past due to the fragmentation of corps and the major role played by civil service trade unions as veto players. The career-based system, the corps system and the school-based orientation of the French civil service have been then growingly challenged. The buzzword of the reform dynamics has been the notion of "métier" which is, in English, a combination of craftsmanship and professionalism. The success of this trend must be related to the transformation and the slow weakening of the corporatist phenomenon in France (Jeannot 2005). Historically speaking, each civil service corps was related to a specific professional academic institution and gathered groups of civil servants with similar training and professional specialisation. Corps were regulated and self-managed, with variations between them, through peer control (for example, road engineers). However, gradually, civil service corps lost their links to one specific professional activity: the most prestigious corps, for instance, have become more and more generalist, encompassing a variety of occupations and positions. Belonging to a Corps has thus become a formal status, opening and facilitating rights for individual members. When speaking of "métier", we, in fact, once again refer to and go back to professional competences and their specific skills. Many of the on going reforms and initiatives now impacting the French civil service are in line with this approach of "métier". Some are limited in scope and incremental; others are more ambitious but they all tend to dilute the corps and make career, income and salaries more depending on the position/post held. Five new trends, with diverse origins that cannot be reduced to the diffusion of the new public management model, can be identified, generating changes in the French civil service (for a detailed argument in French, Jeannot 2008). All these transformative processes, effective or planned, tend to draw the public sector closer to the private sector. If the direction of the dynamics of change is clear, its scale still remains under questions.

While an initial competitive exam based on academic and abstract knowledge remains the rule for hiring civil servants, some exceptions have been emerging. This appears at both ends of the hierarchy with the suppression of the final academic ranking in all civil service schools and specifically at the Ecole nationale d'administration (ENA), to be implemented by 2012, and with a new global tool redefining the various routes to have access to careers in the three segmented French civil services (state, local authorities and hospitals), named "Parcours d'accès aux carrières de la fonction publique territoriale hospitalière et d'Etat" (PACTE). Historically, the ENA has paved the way for different administrative prestigious corps. Prior to 2008, access to these (more or less) prestigious "corps" was determined by highly competitive academic results within the school and by a final ranking at the end of the 
instruction which allowed the students to choose their corps according to their results. By 2012, the incumbents will have to apply for different positions and will be judged by their future employers (grands corps and their related institutions such as the Inspection générale des finances, the Conseil d'Etat or the Cour des Comptes ; ministries for the corps of 'administrateurs civils'). The PACTE recruitments, created in 2006, only affect category C personnel. It is aimed at recruiting people without academic diplomas on the basis of their practical skills. Beneficiaries are recruited without competitive exam on a contract basis. During one or two years, they have access to a mixture of training and professional practice. At the end of this period, they may be recruited as tenured civil servants on the basis of their practical competences. More generally, internal exams for promotion have now tended to be based on practical rather than academic performance. New laws concerning accreditation for work experience that can count towards a qualification (Validation des acquis de l'expérience, VAE) have also been applied in the public sector.

Professional qualification and achievement have also been gradually acknowledged. All ministerial Departments have established competency grids, which could be used to announce the requirements of a position or to adjust progressively human resources to new missions. In certain cases, promotion is no longer linked to seniority but to the competency to manage teams or complex projects. This is the case for police superintendents or engineers. A new kind of bonus, "nouvelle bonification indiciaire", allows now paying a higher salary to employees working in certain positions, especially top level managers. This is concomitant with the growing number of top level positions with specific salary status (named 'Emplois fonctionnels'). By 2010, a new single bonus, related to positions and performance, should be set up in the French civil service replacing all pre-existing bonus. This reform has forced all ministries to establish a quotation of all occupational positions. The 'position part' will constitute $50 \%$ of the bonus (between 10 and $20 \%$ of the salary) and will be directly related to the fulfilled function and, in most of the cases, to the position in the hierarchy. Hence, salary levels tend, at least for the higher levels, to be based more on the position rather than on the corps.

A 2003 report by the Conseil d'Etat (Conseil d'Etat 2003) has even proposed to replace the corps by much larger groups of employees (between 30 and 50) called 'cadres statutaires' (statutory frames). This framework is inspired by the French local civil service model. In this model, the workforce is both organised on activity sector (such as administration, environment, leisure, etc.) and on the hierarchy. The crossing of an activity sector and a hierarchical level defines a group of employees. The reform project is not only aimed at simplifying careers and facilitating mobility but also conceals a more ambitious project: destabilizing trade union corporatism according to the following sociological reasoning. Since decisions concerning individuals are taken inside the corps institutions (for example through the activities of the joint administrative committees, the CAP), several trade unions have developed exclusive sections, only open to members of a given corps. These trade unions tend, consequently, to defend the peculiarities and the members of a given corps. In this context, any change in the size of the corps will destabilize this corporatist structuring. Whether the full 2003 reform project will actually be applied by the state or not remains uncertain. Nevertheless, the significant and steady reduction in the number of corps through mergers (see supra) or the creation of new inter-corps decision-making modalities could lead to the same results.

The European Union has a discrete yet real influence on French civil service reform through different paths. The first is related to the obligation to conform to the rules of free circulation of workers. Although very few citizens of other European countries have in fact sought to enter French civil service, necessary provisions to keep open this possibility have lead to substantial changes in doctrine. A case law concerning a Portuguese hospital director 
willing to manage a French hospital has lead to allowing the person to enter the corps of hospital manager without obtaining the diploma issued by the corresponding higher education school. The fact that these rules don't apply to positions linked to the exercise of "sovereignty" (named "prerogatives of the state"), tend to give weight to a German distinction between Beamte and Angestellte and to confine the status of public servant only to functions such as police or justice. The idea of private contract has even been suggested in a recent official report (Silicani 2008). Second, social agreements brokered at a European level apply to civil services as well as the private sector. This is specifically the case for limitation of working hours and rules hindering successive fixed-terms contracts. The civil service regulation has had to change in order to integrate these European constraints, initially designed to protect workers from the private sector. Third, more indirectly, European open competition policy has lead to major changes in the human resources management of public enterprises. This mode of management has created a very influential model for civil service reform. In particular, these public enterprises (France Telecom, the Post office) have conducted reengineering processes, which have suggested tactical ways of reforming human resource management. These strategies seem to have inspired the large scale reengineering plan of the French administration, launched by the Fillon government since July 2007 and called 'révision générale des politiques publiques' (general public policy review) with explicit reference to the Canadian Program Review (1995-1996) or the UK spending reviews (2002). Within a broad package of decisions, a systematic reorganisation of the territorial state has now been launched through mergers of state field units creating large ministerial services at the regional level and big inter-ministerial units at the départemental one. This very ambitious reform is to generate many problems of human resources management in terms of mobility, career pattern, salary grid, etc. The ongoing movement of merging structures should also favour an intensification of the merger of corps in order to facilitate inter-ministerial mobility. In this perspective, a law on mobility was voted on the 3 August 2009 making available provisions to facilitate such reorganisations. The law creates opportunities for interim work and gives human resources managers the power to force civil servants to change jobs. In case of reorganisation, a civil servant could be fired after declining three proposed alternative jobs.

New public management theories have long been less influential in France than in other European countries (Bezes, 2009). Nevertheless, some ideas have found their way, especially through a major budget reform voted the 1 August 2001 and implemented since 2006. With the implementation of the Organic Act on Budget Legislation (loi organique relative aux lois de finances) named "LOLF", performance measurement has become central to state regulation. The Law involves a major change in the procedures and contents of budget, moving away from line-item budgeting towards public policy and performance sensitive frames. All state activities have been framed in (34) missions and (132) programs, each program with targets and performance indicators. Performance measurement has consequently become central in the relation between the Administration and the Parliament but also between the Budget Directorate and ministries. The new budgetary and managerial framework has been provoking many cascading effects. By offering the (theoretical) possibility for managers in the state field services to make autonomous budgetary choices between appropriations, the reform has paved the way for more devolution in personnel policies so that state field service might develop their own Human Resources Management policies at local level via a strengthening of autonomy and flexibility. Pay-for-performance plans and more differentiated career structures could appear as a logical consequence in the personnel policy of the new managerial approach. However, reforms aimed at improving incentives and especially pay-for-performance plans appeared only recently and have not yet proven to be really pervasive. Experiments have been carried out in the Departments of Finance, Justice and the Police in 2006. A careful examination of these practices shows that 
specific difficulties have arisen. In many situations, managers are reluctant to differentiate between agents. Sometimes the bonuses are in fact used to reinforce the hierarchy between the positions. Even the proponents of this doctrine consider performance bonus more as a pedagogic tool to accompany the LOLF rather than a real incentive system.

\section{Concluding Remarks}

Since the early 2000s, the French civil service has been increasingly and unprecedentedly affected by two dynamics of reform. The first transformative movement has resulted from the indirect effects of the managerial reform of the Budget procedure (the LOLF voted in 2001 and implemented from 2006) and of the on-going reorganization of the territorial state through mergers, launched in 2008 within the General Review of Public Policy. None of these reforms directly targeted the civil service but both contained 'hidden agendas' via the introduction of low-profile tools aimed at provoking destabilizing effects on the civil service and at favouring significant departures from its historical structures. The LOLF has paved the way for more devolution, performance-oriented instruments and cutback management on personnel expenditure, through the use of 'frame-budgeting' and broad aggregated heading allowing more flexible reallocation of appropriations. The current mergers of state units at regional and départemental level are also aimed at producing many cascading effects on the civil service. These reorganizations are to modify career patterns by reducing the number of central and regional administrative directorates within the state and by constraining many state civil servants at local level to join a new merged organisation and to rebuild their mobility plans. These reorganizations will result in significant reallocation of human resources. Inter-ministerial mobility should be then strongly encouraged in this context and there is no doubt that there will be increasing pressures for adopting inter-ministerial statutory frames, much larger than corps and corresponding to the large merged structures.

However, these reforms also put great emphasis on limits to mobility within the existing French civil service. Differences in salaries and bonus between existing corps or economic difficulties to move for civil servants from categories $\mathrm{B}$ and $\mathrm{C}$ are real issues to be tackled. In this direction, the second transformative dynamics corresponds to more direct attempts at reforming the historical features of the French civil service. As analysed in this chapter, there is much evidence that these components have now been directly challenged by European and inner-state pressures and by a large number of initiatives: mergers of corps, the introduction of performance-related pay measures, more emphasis on mobility, interim and fixed term contracts and smooth attempts at bringing together the model of the state civil service status near the local civil service model. Whether the 'grands corps' will resist these new trends is still open to discussion.

At this stage, the future of the French civil service is still uncertain, as there is no single model at the heart of these reforms but several possibly contradictory trends (private sector, New Public Management, local public service, public enterprises, etc.). However, ongoing changes are unprecedented and would have to be evaluated according to two main dimensions. The first is the transformation of the French historical civil service model, specifically the strength of the corporatist phenomenon and the importance of its socializing values. The second suggests considering the differentiated impacts of reforms according to civil servants' positions in the hierarchy, and the possible risk of a dualisation of the administrative labour market. 


\section{Bibliography}

Audier, Florence (2000), 'La transmission du statut dans la fonction publique', Economie et statistiques, $\mathrm{n}^{\circ} 337-338,121-133$.

Baruch, Marc Olivier (1997), Servir l'Etat français. L'administration en France de 1940 à 1944, Paris : Fayard.

Baruch, Marc Olivier (2000), 'Vichy, les fonctionnaires et la République', in M.O. Baruch, V. Duclert (dir.), Serviteurs de l'État. Une histoire politique de l'administration française (18751945), Paris, La Découverte, pp. 523-538

Bessière, Sabine and Julien Pouget (2007), 'Les carrières dans la fonction publique d'Etat: premiers éléments de caractérisation', in Les salaires en France, édition 2007, collection Références, Insee, pp. 51-66.

Bezes, Philippe (2001), 'Defensive vs Offensive Approaches to Administrative Reform in France (1988-1997): the Leadership Dilemmas of French Prime Ministers', Governance, 14, (1), 99-132.

Bezes, Philippe (2007), 'The Hidden Politics of Administrative Reform: Cutting French Civil Service Wages With a Low-Profile Instrument’, Governance, vol. 20, n 1 , janvier 2007, 23 56.

Bezes, Philippe (2009), Réinventer l'Etat. Les réformes de l'administration française (19622008), Paris : Presses universitaires de France (coll. Le Lien Social)

Bezes, Philippe and Patrick Le Lidec (2007), 'French Top Civil Servants Within Changing Configurations. From Monopolisation to Challenged Places and Roles ?' in Edward C. Page and Vincent Wright (eds.), From the active to the enabling state. The changing roles of top officials in European Nations, London: Palgrave/MacMillan, pp. 121-163.

Bezes Philippe and Patrick Le Lidec (2010, forthcoming), 'Steering from the Centre in France in the 2000s. When Reorganizations meet Politicization', in Carl Dahlstrom, B. Guy Peters, Jon Pierre (eds.), Steering from the Centre, Toronto: Toronto University Press.

Biland Emilie (2008), 'Concours territoriaux et institutionnalisation de l'emploi public local (années 1970 - 2000), thèse de doctorat de sociologie de l'EHESS.

Boscher, John Francis (1970), French Finances (1770-1795). From Business to Bureaucracy, Cambridge: Cambridge University Press.

Burdeau, François (1994), Histoire de l'administration française. Du XVIIlème au XXème siècle, Paris : Montchrestien.

Cameron, David R. (1995), 'From Barre to Balladur: Economic Policy in the Era of the EMS' in Gregory Flynn (ed.) Remaking the Hexagon. The New France in the New Europe, Westview Press, pp. 117-157.

Cassese, Sabino (2000), La construction du droit administratif. France et Royaume-Uni, Paris : Montchrestien.

Charle, Christophe (1991), 'Chapitre 6. Anciennes et nouvelles élites', Histoire sociale de la France au XIXème siècle, Paris : Points-Seuil.

Chevallier, Jacques (1996), 'Le statut général des fonctionnaires de 1946 : un compromis durable', La Revue Administrative, Colloque du cinquantenaire du statut de la Fonction Publique, 49, 7-21.

Chevallier, Jacques (1997), 'L'élite politico-administrative: une interpénétration discutée', Pouvoirs, n80, 89-100. 
Church, Clive H. (1981), Revolution and Red Tape. The French Ministerial Bureaucracy (1770-1850), Oxford, Clarendon Press.

Conseil d'Etat (2003), Perspectives pour la fonction publique. Rapport public, Paris: La Documentation française.

Denis, Jean-Michel (2003). 'Le conflit : en grève ? - Bilans et synthèses de deux années de réflexion sur la conflictualité', Séminaire de recherche DARES/GIP-MIS Le conflit dans les rapports au travail : une catégorie encore pertinente, Marne la Vallée : 20 juin.

Dreyfus, Françoise (2000), L'invention de la Bureaucratie. Servir l'Etat en France, en Grande-Bretagne et aux Etats-Unis (XVIII-XXème siècle), Paris : La Découverte.

Dulong, Delphine (1997), Moderniser la politique. Aux origines de la Vème République, Paris : L'Harmattan, coll. Logiques Politiques.

Duport Jean-Pierre and al. (2007), Rapport sur la coordination du travail interministériel, Paris : Mission d'audit de modernisation.

Eymeri, Jean-Michel (2001), La fabrique des énarques, Paris, Economica.

Eymeri, Jean-Michel (2003), 'Frontière ou marches? De la contribution de la haute administration à la production du politique', dans Jacques Lagroye (dir.), La politisation, Paris : Belin, pp. 47-77

Fournier, Jacques (2002). Livre blanc sur le dialogue social dans la fonction publique. Paris : La Documentation Française.

Gaïti, Brigitte (1998), De Gaulle Prophète de la Vème République (1946-1962). Paris: Presses de Sciences Po.

Geniyes, William and Smyrl Marc (2008), 'Inside the Autonomous State. Programmatic Elites, in the Reform of French Health Policy’, Governance, vol.21, n 1, January, 75-93.

Jeannot Gilles (2005), 'De la gestion prévisionnelle des effectifs, des emplois et des compétences aux cares statutaires : la progressive émergence de la notion de 'métier' dans la fonction publique d'Etat', Revue française d'administration publique, 116, 595-608.

Jeannot Gilles (2005), 'Les conditions d'une gestion des compétences des cadres de l'action publique territoriale', Politiques et management public, vol. 23, $\mathrm{n}^{\circ} 2,1-19$.

Jeannot Gilles (2008), 'Réforme de la fonction publique et réorganisation de l'Etat', Esprit, Décembre, 94-109.

Kesler, Jean-François (1997), 'L'énarchie n'existe pas', Pouvoirs, n80, 23-42.

Kessler Marie-Christine (1978), L'E.N.A. La politique de la haute fonction publique. volume histoire. Paris : Presses de la FNSP.

Legendre Pierre (1992), Trésor historique de l'État en France. L'administration classique, Paris, Fayard (1 ${ }^{\text {ère }}$ éd. 1968).

Lucifora Claudio, Meurs Dominique (2006), "The Public Sector Pay Gap in France, Great Britain and Italy", Review of Income and Wealth, vol. 52, ${ }^{\circ} 1,43-59$.

Meininger Marie-Christine (2001), 'The development and Current Features of the French Civil Service System' in A. J. G. M. Bekke, Frits M. Meer, Civil service systems in Western Europe, Cheltenham, Edward Elgar, pp.

Ministère du budget des comptes publics et de la fonction publique (2008), Rapport annuel sur l'état de la fonction publique. Faits et chiffres 2007-2008, Paris: La documentation française.

Mouriaux, René (2000). 'La conflictualité dans les services publics', in Luc Rouban (dir.), Le service public en devenir. Paris : L'Harmattan, pp. 157-176. 
Mousnier, Roland (1974), Les institutions de la France sous la monarchie absolue. Paris : PUF.

Perrin Bernard (2005), 'Les emplois de direction dans les collectivités territoriales : la capacité d'adaptation, vertu première', Revue française d'administration publique, 116, 583594.

Pouget Julien (2005), "La fonction publique vers plus de diversité", in France, Portrait Social, édition 2005-2006, Insee, p. 143-162.

Quermonne, Jean-Louis (1982) 'Politisation de l'administration ou fonctionnarisation de la politique ?', in F. de Baecque and J.-L. Quermonne (dir.), Administration et politique sous la Vème République, Paris: Presses de la FNSP, pp. 329-360.

Rehfeldt, Ugo and Vincent, C. (2002). Négociations sur les transformations de l'emploi dans les services publics. Rapport de synthèse du séminaire organisé par l'IRES.

Rosanvallon, Pierre (1990), L'Etat en France de 1789 à nos jours, Paris, Le Seuil.

Rouban, Luc (1998), The French Civil Service. Paris : La Documentation française.

Rouban, Luc (2004a), La fonction publique. Paris : Repères La Découverte.

Rouban, Luc (2004b), 'Les cabinets ministériels du gouvernement Jospin (1997-2002)', Revue administrative, $\mathrm{n}^{\circ} 339,230-248$

Rouban, Luc (2004c), «Politicization of the civil service in France. From Structural to Strategic Politicization", in B. Guy Peters, Jon Pierre (eds.), Politicization of the Civil Service in Comparative perspective. The quest for control, London: Routledge, pp. 81-100.

Rouban Luc (2007), 'Public Management and Politics : Senior Bureaucrats in France', Public Administration, vol. 85, 2, 473-501.

Rouban, Luc (2009), 'La politisation de l'administration en France ou la privatisation de l'Etat', Télescope, hiver.

Roubieu Olivier (1994), 'Le modèle du "manager". L'imposition d'une figure légitime parmi les hauts fonctionnaires des collectivités locales', Politix, 28.

Saglio, Jean (2003), Les relations professionnelles dans le public. Texte non publié.

Saglio Jean (2005), 'Le droit à la carrière des officiers de la marine', Revue française d'administration publique, 116, 639-650.

Sawicki, Frédéric and Pierre Mathiot (1999), 'Les membres des cabinets ministériels socialistes en France (1981-1993)' Revue française de science politique 1 \& 2, 3-29 \& 231264.

Schrameck, Olivier (2001), Matignon, rive gauche 1997-2001, Paris: Le Seuil.

Shefter Martin (1994), 'Party, Bureaucracy and Political Change in the United States' dans Martin Shefter, Political Parties and the State. The American Historical Experience, Princeton : Princeton University Press, pp. 61-97

Silberman Bernard S. (1993), Cages of Reason The Rise of the Rational State in France, Japan, The United States and Great-Britain, Chicago: Chicago University Press.

Silicani Jean-Louis (2008), Livre blanc sur l'avenir de la fonction publique. Faire des services publics et de la fonction publique des atouts pour la France, Paris : La Documentation française.

Siwek-Pouydesseau Jeanne (1989), Le syndicalisme des fonctionnaires jusqu'à la guerre froide, 1848-1948, Lille : Presses Universitaires de Lille.

Siwek-Pouydesseau Jeanne (2001), Les syndicats des fonctions publiques au XXème siècle. Paris : Berger-Levrault. 
Thomas Yves (1995), Histoire de l'administration, Paris : La Découverte (coll. Repères). 